\title{
Asian students' intercultural preparation for academic mobility: getting ready for diversities or reproducing the expected?
}

\begin{abstract}
Many academic contributions on Asian students abroad focus on their lack of interactions with the local population and their unpreparedness for intercultural encounters. Asian students appear as socially deficient and unfit for the new environment. These assumptions are problematic because they do not take into consideration the input prospective students receive prior to their departure through institutional training and unsupervised research on the host country under the studentôs own initiative or a mix of both. Representations are also based on cultural differentialism which locates individuals in distinct, boundary-making categories, thus silencing most forms of individual diversities in the home and host societies. The main question arising thus deals with the kind of input that Asian future mobile students acquire, which is susceptible to impact their intercultural experiences. Data used for this article come from three different sets of interviews with Asian mobile students. Using a critical discourse approach, the discourses of these students are analysed from the perspective of their preparation to move to the host destination. Recurrent othering processes $ठ$ both from institutional actors and from the students themselvesð appear prior to departure, independent of the studentsô origin and destination. Rather than blaming students, it would be more significant to look at what materials are available for them prior to their departure.
\end{abstract}

Keyword: Asian students; Chinese students; Malaysian EduHub; Malaysian students; Student mobility 